\title{
Landholders' Satisfaction with Compulsory Acquisition and Compensation Process in Bauchi, Nigeria
}

\author{
Muhammad Usman Adekunle ${ }^{1}$, Hadiza Tijjani Bello ${ }^{1}$, Samirah Ibrahim Jibril ${ }^{1}$, Ibrahim Idris ${ }^{1}$
}

\author{
${ }^{1}$ Abubakar Tafawa Balewa University \\ Tafawa Balewa Way, P. M. B. 0248, Bauchi, 740272, Nigeria
}

DOI: $10.22178 /$ pos.65-6

JEL Classification: Q15

Received 05.11.2020

Accepted 25.12.2020

Published online 31.12.2020

Corresponding Author:

Muhammad Usman Adekunle

babaucy@gmail.com

(c) 2020 The Authors. This article

is licensed under a Creative Commons

Attribution 4.0 License @) (1)

\begin{abstract}
This research aims to assess Landholder's satisfaction with the compulsory acquisition and compensation process in Bauchi to identify areas of weakness in the process and propose areas of improvement. The study adopted the quantitative approach and data collected through questionnaire survey from 327 landholders affected by the compulsory acquisition and compensation exercise by the Bauchi State Government. The data collected were subjected to descriptive with mean ranking, frequency distribution. The study revealed that landholders were very satisfied before the process of compulsory acquisition, during the process of mandatory purchase, they were also happy. Still, during the compensation process, they were very dissatisfied. It recommended that the Government should make the process of compensation more transparent.
\end{abstract}

Keywords: landholder's satisfaction; compulsory acquisition; compensation process.

\section{INTRODUCTION}

The author [13] opined that the way governments in most developing countries exercise this power undermined tenure security and little or no compensation are usually paid; this results in a negative effect on equity and transparency. The author [7] suggested that lack of adequate, fair and just compensation results in prevalent resistance to land acquisition. The author [14] agreed with Kakulu's view and stated that inadequacy in the provisions of the laws and delay in payment of compensation are the significant reasons for the inequity of the compensation practice in Nigeria. The compensation paid is usually compounded where the process is implemented poorly, which led to the Government's resisting compulsory land acquisition.

Thus, the Landholder's have no control over the situation since the Government has the right to acquire the property compulsorily without their consents for the overriding public interest [10, 18]. According to [3] the amount paid as compensation is usually determined by the government agency without much consultation with affected claimants. Where a property is compulsorily acquired, it is typically the government agency that makes inquiries into the value of such land and determines the already identified government principles' compensation value.

Thus, there is the likelihood that the computed compensation value may be below the expectation of the claimants [6]. Since the acquisition directly affects the Landholder's, the exercise should be geared towards their benefit and satisfaction [2].

It is against this background this study seeks to explore the perception of Landholder's affected by compulsory acquisition of land in Durum, Bauchi to ascertain their level of satisfaction with the exercise.

This research's scope is restricted to the perception of Landholder's affected by compulsory acquisition of land and compensation paid for the development of Abubakar Tafawa Balewa International Airport and Airforce Base, which is located along Bauchi-Kano road. It does not include any other compulsorily acquired land in Bauchi. 
This research is limited to the Landholder's whose land was compulsorily acquired for the said project to override the public interest in the study area.

The statutory provisions of the Land Use Act of 1978 to compulsory acquisition and Compensation in Nigeria has raised several issues, and concerns among stakeholders in the administration of land especially such compulsory acquisition are done for urban properties. Inadequate compensation paid as stipulated under section 29 of the Land Use Act of 1978 is grossly inadequate to the payment of just, fair and adequate compensation. It restricts the number of heads of claims and nonpayment for bare land undeveloped land [8].

The author [5] noted that most affected Landholder's usually expected to receive compensation generally in monetary terms to restore them to where they were before the dispossession such as to buy new land, build a new structure, and cater to others losses as a result of the relocation. He concluded that the Land Use Act only provides compensation, far from being "adequate".

Non-inclusion of just compensation principle: under section 29 of the Land Use Act of 1978, which provides for the payment of compensation does not mention the code of just term compensation or value to the landowner. The focus of "just compensation" aims at providing disposed groups with adequate financial compensation.

Basis and method of investment: the origin and method usually employed do not recognise the value which the property can command in an open market but is based on replacing the improvements and crops. The predetermined rate to determine the depreciated replacement cost of buildings can hardly yield a just and adequate compensation to assist Landholders in replacing their construction, resulting in inequity [1].

Undefined interest in land: usually more than one part may exist in landed property, for example, freehold and leasehold interest in land, thus when compulsorily acquiring land it is usually the interests that exist on such land is being received. The Land Use Act assumed compensation for the earned interest should be made to only the occupier of the ground, and it is the doctrine that land title is vested in the governor. Thus there exist multiplicities of interest.

\section{METHODOLOGY}

The quantitative research approach is adopted in this research due to the nature of the research problem that involves the Effects of Landholder's awareness and involvement in compulsory acquisition and compensation paid in Bauchi. According to [4] quantitative research approach is the best research approach when the problem is deterministic and reflects the fact that causes determine the outcome. Thus the use of the quantitative system in the research was justifiable. The author [4] opined that the quantitative approach shows the relationship between variables aimed at testing theories.

Thus quantitative methods involve collecting data, numerically analysing and interpreting the data. The descriptive survey design was adopted for this research because it generates answers to research problems $[12,17]$.

The target population is derived from landholders whose lands were compulsorily acquired for Airport and Airforce Base's development in Bauchi situated in Durum village.

For this research, the sample frame consists of 1128 landholders for Airport and 985 landholders for Air Force Base, a total of 2113 landholders (Ministry of Lands and Survey Bauchi) whose land was compulsorily acquired and compensation paid in Durum.

This study's target population was all the Landholder's affected by the compulsory acquisition and compensation exercise by the Bauchi State Government. A population consists of a group that shares common characteristics from which individuals or units are chosen out of the study population [11]. This research's sample size will be selected using the [9] sample table.

\section{RESULTS}

The research conducted will be analysed using different types of test to achieve the desired objectives. Objectives one-three will be analysed using the mean ranking for the variables. The descriptive test will be carried out to ensure the mean will be entered correctly to accomplish this. For objective four regression analysis will establish the effect between the research constructs, using the SPSS version 21 software package to carry out the study. 
However, the difference in descriptors, the construct have a uniform mean ranking scale. Accordingly, the ranks were numbered between level one (1), which was the lowest level to level five (5), which was the highest level. This study adopted the mean score decision interval based on the works [16] from which the following interval decisions were deduced (1-1.80)=Very low; (1.81-2.60)=Low; (2.61-3.40)=Moderate; (3.414.20)=High; (4.21-5.0)=Very high (Table 1).

Table 1 - Cronbach's Alpha Value of questionnaire constructs

\begin{tabular}{|c|c|c|c|c|}
\hline No & Variables & Item Statistics / No of construct & Cronbach's Alpha Value & Reliability status \\
\hline 1 & Awareness & 10 & 0.79 & Acceptable \\
\hline 2 & Involvement & 9 & 0.79 & Acceptable \\
\hline 3 & Satisfaction & 14 & 0.87 & Good \\
\hline
\end{tabular}

Validity refers to the extent to which a scale measures what it is meant to measure [15]. The author [4] opined that there is another validity: criterion validity and content validity; construct validity is the overriding objective. It has focused on whether the scores serve a useful purpose and have positive consequences when used in practice. For this research, construct validity was adopted.

As revealed in table 2 above landholders were very satisfied with the acquisition notice issued to them.

Table 2 - Landholders satisfaction with compulsory acquisition and compensation process

\begin{tabular}{|l|c|l|l|l|}
\hline \multicolumn{1}{|c|}{ Variables } & Mean & Std. Deviation & Ranking & Remark \\
\hline Acquisition notice & 4.5593 & .70197 & 1 & Very High \\
\hline Communication channels & 4.4741 & .70399 & 2 & Very High \\
\hline The computation of land and economic trees & 4.4741 & .57623 & 3 & Very High \\
\hline Items to be compensated & 4.4000 & .49081 & 4 & Very High \\
\hline With the way Government handles acquisition & 4.1556 & .83925 & 5 & High \\
\hline The entire process & 4.1185 & .86701 & 6 & High \\
\hline The process involved in acquisition and compensation & 4.0407 & .78212 & 7 & High \\
\hline Process of Compensation for the acquired land & 3.4926 & 1.21252 & 8 & High \\
\hline Amount paid as compensation reflects your expectation & 3.2667 & 1.26843 & 9 & Moderate \\
\hline With the actual computation of your assets & 3.2296 & 1.59898 & 10 & Moderate \\
\hline Amount to be paid as compensation for economic trees & 3.1889 & 1.40017 & 11 & Moderate \\
\hline Amount to be paid as compensation for land & 3.1407 & 1.20817 & 12 & Moderate \\
\hline Promptness of Compensation paid & 1.9963 & .80656 & 13 & Low \\
\hline Satisfaction with the compensation paid & 1.4037 & .63655 & 14 & Very Low \\
\hline
\end{tabular}

The communication channels between them and the Government, amount to be paid as compensation for land, items to be compensated such as land and economic trees with the way Government handles compulsory acquisition and Compensation in Nigeria. The process involved the mandatory addition of land and compensation with a mean score of 4.5593, 4.4741, 4.4741, 4.4000, 4.1556, 4.1185 and 4.0407 ranked 1st, 2nd, 3rd, 4th, 5th, 6th and 7th respectively.

Landholders were satisfied with the process of compensation for the compulsorily acquired land. Amount to be paid as compensation reflects their expectations, with their assets' actual computation before payment. Amount to be paid as compensation for economic trees and land was adequate with a mean score of 3.4926, 3.2667, 3.2296, 3.1889 and 3.1407 ranked 8th, 9th, 10th, 11 th and 12 th respectively.

Landholders were very dissatisfied with the promptness of compensation paid and with the balance paid with mean score 1.9963 and 1.4037 ranked 13th and 14th respectively.

The result revealed that the level of landholders' satisfaction with the compulsory acquisition and compensation process is very high, high, moderate, low and very low. 


\section{CONCLUSION}

This study aimed to assess Landholder's awareness and involvement in the compulsory acquisition of land on their satisfaction with compensation process in Bauchi to identify areas of weaknesses in the process. The study came when the Government compulsorily acquires land for overriding public interest to provide infrastructural facilities.

\section{REFERENCES}

1. Akujuru, V. A., \& Ogbonda, U. J. (2016). Rationalising the Contemporary Issues in the Valuation of Land for Infrastructural Development in Nigeria. Donnish Journal of Research in Environmental Studies, 3(1), 1-7.

2. Akujuru, V., \& Ruddock, L. (2015). Compulsory acquisition practices and the determination of compensation payable in the Niger Delta. Journal of Land Administration in Eastern Africa, 1(1), 75-84.

3. Ataguba, J. O. (2014). Towards a Disturbance-Integrated Compensation Method for Land Expropriation: A Case of Rwanda. Retrieved from https://library.itc.utwente.nl/papers_2014/msc/la/ataguba.pdf

4. Creswell, J. W. (2014). Research design: qualitative, quantitative and mixed method approaches (4th ed.). Thousand Oaks: Sage Publications, Inc.

5. Ezenwa, N. I. (2009). Claimants Perception of Adequacy of Compensation in Enugu State (Master's thesis). Nsukka.

6. Honig, L., \& Mulenga, B. P. (2015). The Status of Customary Land and the Future of Smallholder Farmers Under the Current Land Administration System in Zambia. Retrieved from https://ageconsearch.umn.edu/record/212908/files/wp101.pdf

7. Iyanda, A. (2014). Communal Land Acquisition and Valuation for Compensation in Nigeria. International Journal of Scientific and Research Publications, 4(11), 1-7.

8. Kakulu, I. I. (2008). The assessment of compensation in compulsory acquisition of oil-and gas-bearing lands in the Niger Delta. Retrieved from https://www.researchgate.net/publication/259969693_The_assessment_of_compensation_in_c ompulsory_acquisition_of_oil_and_gas_bearing_lands_The_Niger_Delta_experience

9. Krejcie, R. V., \& Morgan, D. W. (1970). Determining sample size for research activities. Retrieved from https://home.kku.ac.th/sompong/guest_speaker/KrejcieandMorgan_article.pdf

10. Larbi, W. O. (2008). Compulsory Land Acquisition and Compensation in Ghana: Searching for Alternative Policies and Strategies. Retrieved from https://www.fig.net/resources/proceedings/2008/verona_fao_2008_comm7/papers/09_sept/ 4_1_larbi.pdf

11. Mathers, N., Fox, N., \& Hunn, A. (2009). Survey and questionnaires. Nottingham: The NIHR RDS for East Midlands.

12. Munubi, S. L. (2016). Quest for "Just Terms Of Compensation" in Involuntary Resettlement Policy and Praxis in Kenya: a Case Study of Nairobi-Hhika Highway (Doctoral Thesis). Nairobi.

13. Ndjovu, C. E. (2015). Compulsory land acquisitions in Tanganyika: revisiting the British colonial expropriation principles and practices. International Journal of Scientific and Technology Research, 4(12), 1-5.

14. Nuhu, M. B. (2008). Compulsory Purchase and Payment of Compensation in Nigeria: a Case Study of Federal Capital Territory (FCT) Abuja. Nordic Journal of Surveying and Real Estate Research, 3, 102-126.

15. Pallant, J. (2002). SPSS SURVIVAL MANUAL: A step by step guide to data analysis using SPSS for Windows. Retrieved from http://www.fao.org/tempref/AG/Reserved/PPLPF/ftpOUT/Gianluca/stats/SPSS.Survival.Manu al.ISBN.0-335-20890-8.pdf

16. Ramli, L., Mohamed, Z., Abdullahi, A. M., Jaafar, H. I., \& Lazim, I. M. (2017). Control strategies for crane systems: A comprehensive review. Mechanical Systems and Signal Processing, 95, 1-23. doi: 10.1016/j.ymssp.2017.03.015 
17. Saunders, M., Lewis, P., \& Thornhill, A. (2007). Research Methods for Business Students (5th ed). Harlow: Prentice Hall.

18. Tagliarino, N. (2017). The Status of National Legal Frameworks for Valuing Compensation for Expropriated Land: An Analysis of Whether National Laws in 50 Countries/Regions across Asia, Africa, and Latin America Comply with International Standards on Compensation Valuation. Land, 6(2), 37. doi: 10.3390/land6020037 